Please do not destroy or throw away this publication. If you have no further use for it, write to the Geological Survey at Washington and ask for a frank to return it

\title{
A FLORA OF POTTSVILLE AGE FROM THE MOSQUITO RANGE, COLORADO
}

BY

CHARLES B. READ

Shorter contributions to general geology, 1934-35

(Pages 79-96)

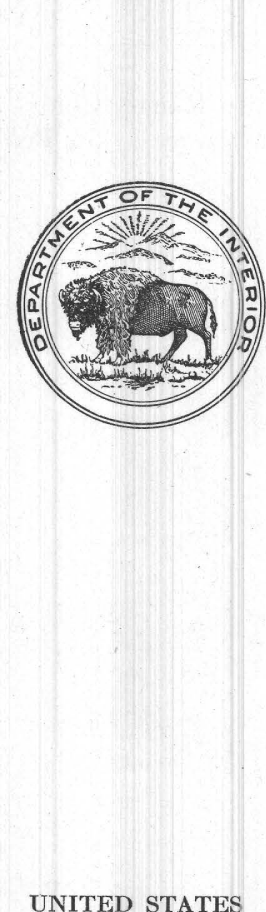

GOVERNMENT PRINTING OFFICE

WASHINGTON : 1934

For sale by the Superintendent of Documents, Washington, D. C. - _ _ _ Price 10 cents 


\section{CONTENTS}

Abstract__

Introduction, .

Geologic relations of the flora

Composition of the flora

Systematic descriptions

\section{ILLUSTRATIONS}

Plates 16-18. Plants of Pottsville age from the Mosquito Range, Colo

FIgURE 3. Sections of lower part of the Weber(?) formation at Evans Peak and Pennsylvania Mountain, Colo 


\title{
A FLORA OF POTTSVILLE AGE FROM THE MOSQUITO RANGE, COLORADO
}

\author{
By Charles B. Read
}

\begin{abstract}
Seventeen species of fossil plants from the lower part of the Weber (?) formation of the Mosquito Range, Colo., show that the age of the containing beds is lower Pennsylvanian and indicate a correlation with the Pottsville formation of the eastern United States. Although predominantly a typical Carboniferous flora, certain of the species are unique. Lepidostrobus weberensis, $\mathrm{n}$. sp., Adiantites rockymontanus, $\mathrm{n}$. sp., and Dactylophyllum johnsoni, n. gen. and sp., are proposed. Other forms recognized include stigmaria verrucosa, Calamites sp., Asterophyllites longifolius?, Neuropteris dluhoschi, $N$. heterophylla, N. gigantea?, Sphenopteris asplenioides, S. cf. S. microcarpa, S. cheathami, Diplotmema patentissima, Cordaites sp., Cordaianthus sp., Cordaicarpon sp., and Trichopitys whitei.
\end{abstract}

\section{INTRODUCTION}

This paper describes a small fossil flora from the vicinity of Leadville, central Colorado. The beds from which the flora was collected have long been referred to as the "Weber formation", though with considerable doubt on the part of many geologists that all the beds so named in Colorado are correlative with the Weber quartzite of northeastern Utah. In current usage these Colorado beds are designated the "Weber (?) formation."

The remains of plants from the upper Paleozoic sections of Colorado have received very little attention. A few small collections of Permian plants have been made at several stations, and a florule from the Glen Eyrie shale member of the Fountain formation has been identified by White. ${ }^{1}$ Small lots of very fragmentary material have been collected from other localities by several individuals, but these have generally been of negligible value.

The plants which are dealt with here were discovered by J. H. Johnson and C. D. Hier, of the Colorado School of Mines, during the summer of 1930, while engaged in a stratigraphic study of the Pennsylvanian sedimentary rocks in the Mosquito Range. In September of the same year the writer visited the localities in company with Messrs. Johnson and Hier and added a quantity of material to the collections previously made. These localities are almost due east of Leadville, on the flanks of Evans Peak and Pennsylvania Mountain. Their more specific location is given on another page.

\footnotetext{
${ }^{1}$ Finlay, G. I., U.S. Geol. Survey Geol. Atlas, Colorado Springs folio (no. 203), p. 7, 1916.
}

Much advice and constructive criticism have been given during the course of the study by Mr. David White, to whom grateful acknowledgments are due.

\section{GEOLOGIC RELATIONS OF THE FLORA}

Two localities on Evans Peak and Pennsylvania Mountain furnish the plant material described here. In this area the Weber (?) formation lies above the Leadville limestone with apparent conformity. Its general features have been summed up by several geologists in reports on the Leadville mining district $^{2}$ and on the stratigraphy of the Pennsylvanian formations of Colorado. ${ }^{3}$ It is sufficient to say here that the formation comprises a lower thin shaly division and a much thicker upper sandy and conglomeratic division, the two aggregating 1,000 feet in the Leadville district but thickening to 2,800 feet in adjacent regions. These are often spoken of as the t"Weber shales" and +"Weber grits." " 4 Thin beds of limestone containing invertebrates occur at several horizons. Both the shales and the sandstones are highly micaceous.

Johnson has published sections which give in detail the lithology of the formation. ${ }^{5}$ These sections definitely establish the position of the plant horizons in the lower part of the formation and show their relations to the enclosing strata, some of which may be identified at other localities, as well as indicating their position with reference to invertebrate faunas.

The relations of the sections at Evans Peak and Pennsylvania Mountain are diagrammatically shown in figure 3, which has also been prepared by $\mathrm{Mr}$. Johnson. It will be seen that the plant-bearing beds (bed 17 (locality 8049), Evans Peak; bed 5 (locality $8050)$, Pennsylvania Mountain) are at very nearly the same position in the two sections. Their exact equiva-

\footnotetext{
2 Emmons, S. F., Geology and mining industry of Leadville, Colo.: U.S. Geol. Survey Mon. 12, p. 69, 1886. Emmons, S. F., Irving, J. D., and Loughlin, G. F., Geology and ore deposits of the Leadville mining district, Colo.: U.S. Geol. Survey Prof. Paper 148, pp. 38-39, 1927.

${ }^{8}$ Girty, G. H., The Carboniferous formations and faunas of Colorado: U.S. Geol. Survey Prof. Paper 16, pp. 242-243, 258 et seq., 1903. Johnson, J. H., Paleozoic formations of the Mosquito Range, Colo.: U.S. Geol. Survey Prof. Paper 185-B, 1934.

4 A dagger ( $\dagger$ ) preceding a geologic name indicates that the name has been abandoned or rejected for use in classification in publications of the U.S. Geological Survey. Quotation marks, formerly used to indicate abandoned or rejected names, are now used only in the ordinary sense.

${ }^{5}$ Johnson, J. H., op. cit., pp. 33-42.
} 


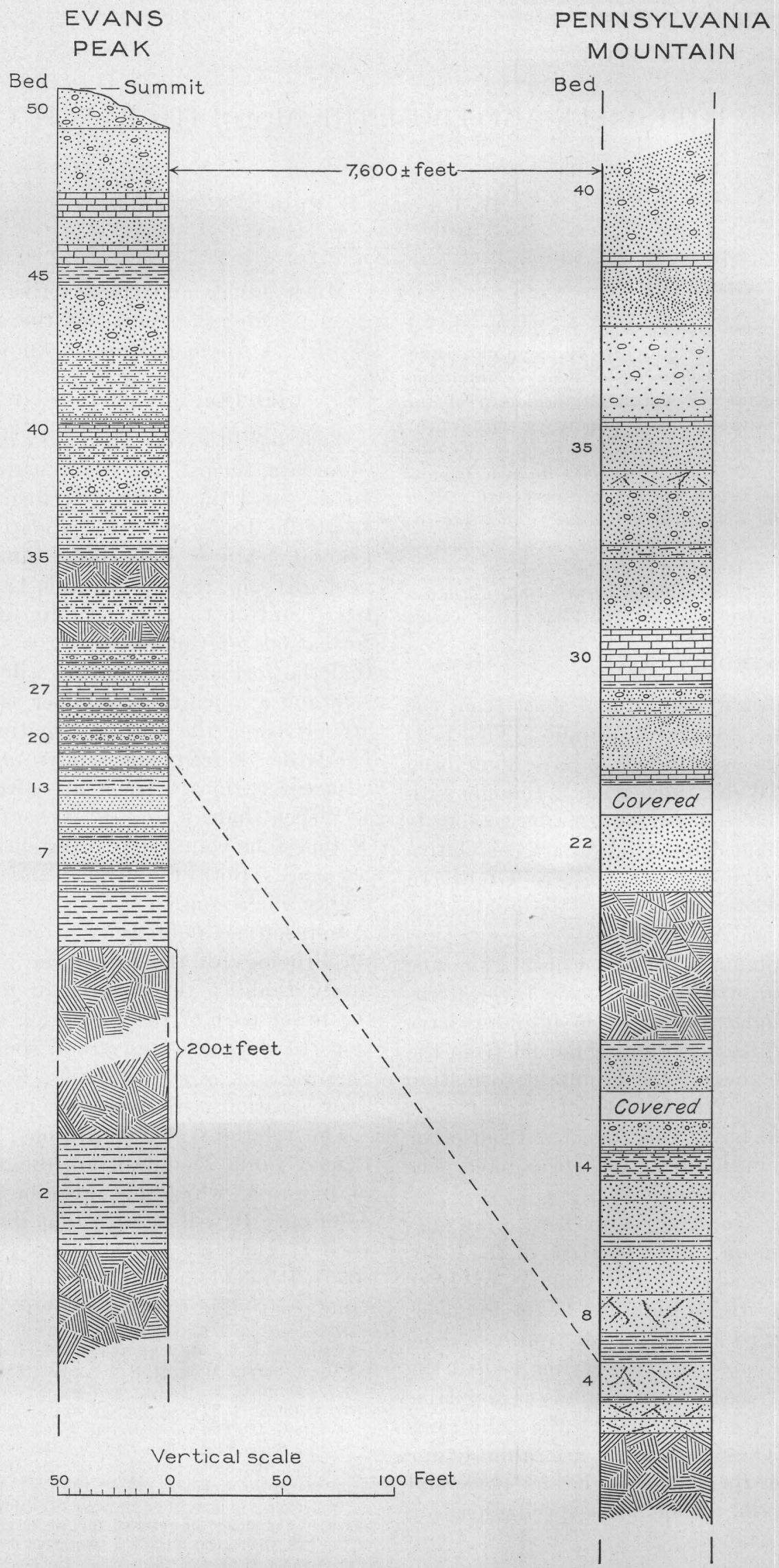

Figure 3:-Sections of lower part of the Weber (?) formation at Evans Park and Pennsylvania Mountain, Colo. 
lence is not yet established, but the geologic and stratigraphic relations suggest that there cannot be more than 100 feet of difference. The floral evidence is in complete accord with this.

A large fauna has been listed from the Weber (?) formation in the area around Leadville. The study of this fauna caused Girty ${ }^{6}$ to conclude that "the Weber and lower Maroon formations and the Weber shales and Weber grits come very early in Pennsylvanian time and are probably older than any beds of the Kansas and Nebraska sections." More recent work has shown that the Maroon is of Permian age, but the opinion regarding the age of the Weber (?) has been generally accepted.

The collections of fossil plants from the lower part of the Weber (?) corroborate the evidence of the fauna in pointing out the early Pennsylvanian age of at least this part of the formation. Some of the species are identical with or closely related to common and characteristic species of the Pottsville of the Appalachian region. These are as follows:

\section{Sphenopteris asplenioides Sternberg \\ Sphenopteris cf. S. microcarpa Lesquereux \\ Sphenopteris cheathami (Lesquereux) Read, n. comb. \\ Diplotomema patentissima (Ettingshausen) Stur. \\ Neuropteris gigantea Sternberg? \\ Neuropteris heterophylla Brongniart \\ Neuropteris dluhoschi Stur. \\ Stigmaria verrucosa (Martin) S. A. Miller \\ Cardiocarpon sp.}

In addition, there are several specifically unidentifiable forms and several new forms which do not give any unusual aspect to the flora. It is notable that this aggregate of species is comparable to floras of the middle Pottsville. The evidence is much too weak, however, to allow any definite statement of such a refined correlation.

Three of the species that are represented in the Evans Peak collection are unique. These are Trichopitys whitei, Dactyiophyllum johnsoni, and Adiantites rockymontanus. The first two in particular are unusual forms belonging to genera previously unknown in America and having a very puzzling discontinuous stratigraphic and areal distribution in Europe. Although the genus Adiantites is by no means uncommon in early Pennsylvanian strata, Adiantites rockymontanus is suggestive of pre-Pottsville forms and shows peculiarities that makes it very distinct.

The lower Weber(?) flora has been compared. with indifferent success, with several lots of plants from formations that are regarded as essentially the equivalent of the Weber(?). The black shales of the Glen Eyrie member of the Fountain formation

\footnotetext{
${ }^{6}$ Girty, G. H., op. cit., p. 264.
}

have been correlated with the lower Weber(?) or †Weber shales and should contain floral evidence to justify this correlation. A flora from these beds has been studied by David White, and a report is included in the Colorado Springs folio. ${ }^{7}$ Recent collections have amplified the number of species. Only three, Stigmaria verrucosa, Sphenopteris asplenioides, and a very doubtfully identified Adiantites rockymontanus, are present in the Weber(?) flora. White inclined to the opinion that the Glen Eyrie flora is of upper Pottsville age. There can be no doubt that it has a younger appearance than the Weber(?) flora. The other collections that have been studied are too fragmentary to allow any careful comparison.

This evidence may be summed up by saying that the lower portion of the Weber(?) formation bears a flora which is indubitably Pottsville. Certain of the species indicate a reference to the middle Pottsville, but these are insufficient to permit a dogmatic statement to that effect. The flora of the Glen Eyrie member of the Fountain formation is tentatively regarded as somewhat younger than the Weber(?) flora, although also of Pottsville age.

\section{COMPOSITION OF THE FLORA}

A systematic list of the species recognized in the Evans Peak flora is given below.

Pteridophyta :

Lycopodiales :

Lepidodendraceae:

Lepidostrobus weberensis. Stigmaria verrucosa.

Equisetales:

Calamariaceae :

Calamites sp.

Asterophyllites longifolius?

Spermatophyta :

Gymnospermae :

Cycadofilicales:

Neuropterideae:

Neuropteris dluhoschi.

Neuropteris heterophylla.

Neuropteris gigantea?

Sphenopterideae :

Sphenopteris asplenioides.

Sphenopteris cf. S. microcarpa.

Sphenopteris cheathami.

Diplotmema patentissima.

Adiantites rockymontanus.

Cordaitales:

Cordaites sp.

Cordaianthus sp.

Cordaicarpon sp.

Position uncertain:

Palaeophyllales:

Trichopitys whitei.

Dactylophyllum johnsoni.

${ }^{7}$ Finlay, G. I., U.S. Geol. Survey Geol. Atlas, Colorado Springs folio (no. 203), p. 7, 1916. 
The flora, it will be seen, contains 17 species of fossil plants, 15 of which are characteristic of the American Carboniferous and 2 are unique. The present status of the flora is, however, very incomplete, and the number of species will probably be greatly increased whẹn further studies are made.

\section{SYSTEMATIC DESCRIPTIONS}

\section{PTERIDOPHYTA}

\section{IYCOPODIALES}

\section{LEPIDODENDRACEAE}

Lepidostrobus weberensis Read, n. sp.

Plate 16, figures 1, 2, 4

Strobilus linear, 34 to over 74 millimeters in length, broadest at base and tapering gradually upward to an acutely rounded apex; axis about 1 millimeter in width, with very narrowly fusiform sporophyll cushions less than 0.25 millimeter broad and from 1 to 2 millimeters long, the vascular and parichni scars unobservable. Sporophylls crowded, about 1 millimeter distant, spirally arranged, at right or slightly acute angles to axis and becoming more acute apically, the keel 5 to 8 millimeters long, narrow, thin, the sporangia seated on the adaxial surface, 4 to 7 millimeters long, low, the crest line nearly straight or slightly convex, rounded distally, apparently attached by whole of base; blade arching rapidly from point of inflection to form a narrowly obtuse or nearly right angle to keel, overlapping next four or five more distal sporophylls, thin, narrow, probably acuminatelanceolate, midrib not observable. The whole cone has a very compact aspect.

Microspores occasionally observed in distal sporangia; megaspores not observed.

Owing to the abundance of these strobili at locality 8050 it has been deemed best to describe them as new in spite of their poor preservation. Figure 1 shows one of the better strobili and permits the essential features to be made out. The extremely slender form of the cone is typical, as is the compactness. The axis is very small and bears elongate sporophyll cushions. The keels depart at very nearly right angles to the axis; the blades are flexed strongly upward and are imbricate. In figure 4 a similar strobilus is illustrated.

Figure 2 gives some idea of the external aspect of the strobilus and demonstrates somewhat the overlapping of the blades.

Comparable forms are few. Lepidostrobus linearis Goeppert ${ }^{8}$ and $L$. attenuatus Goeppert ${ }^{9}$ furnish some points of similarity insofar as general shape is con-

\footnotetext{
8 Goeppert, H. R., Die fossile Flora der permischen Formation : Palaeontographica, vol. 12 , pp. $140-141$, pl. 19, figs. 1-7, 1864.

${ }^{\circ}$ Idem, pp. 141-142, pl. 19, figs. 8-13 ; pl. 52, figs. $4,7,1864$.
}

cerned, but both have larger and heavier axes, keels, and blades. In the Lacoe collection of fossil plants in the United States National Museum there is a specimen (no. 16042; 305 A) labeled "Lepidostrobus variabilis Lindley and Hutton" which is extremely slender for its size and which may be wrongly identified. With it $L$. weberensis compares in many respects but is much smaller and fails to show the heavy axis that is present in the Lacoe plant.

No suggestion can be made concerning the characteristics of the plant that bore the strobili other than that it was a lepidophyte. These cones and Stigmaria verrucosa comprise the whole of the remains of such plants which have so far been collected from the localities.

Lepidostrobus weberensis is so unusual a form and its affinities are so vague that it furnishes nothing of value concerning the age of the deposits. The species name, weberensis, refers to the formation from which it was obtained, the Weber(?).

Occurrence: Bed 17 of Evans Peak section; collected by J. H. Johnson, C. D. Hier, and C. B. Read.

\section{Stigmaria verrucosa (Martin) S. A. Miller}

Plate 16, figure 5, c

Phytolithus verrucosus Martin, Outlines of an attempt to establish a knowledge of extraneous fossils on scientific principles, p. 203, 1809; Petrificata derbiensis, p. 23, pls. 11-13, 1809.

Steinhauer, Am. Philos. Soc. Trans., vol. 1, p. 268, pl. 4 figs. 1-4, 1818.

Variolaria ficoides Sternberg, Flora der Vorwelt, vol. 1, fasc. 1, p. 24 , pl. 40 , figs. $1-3,1820$.

Stigmaria ficoides (Sternberg) Bromgniart, Mus. hist. nat. Mém., vol. 8, pp. 228, 239, p. 1, fig. 7, 1822.

Stigmaria verrucosa S. A. Miller, American Paleozoic fossils, p. $40,1877$.

White, U.S. Geol. Survey Mon. 37, pp. 244-245, 1899.

In the Evans Peak and Pennsylvania Mountain collections there are a number of specimens of shale bearing fragments of Stigmaria verrucosa. These are too well known to necessitate any description and are important only in indicating the presence of lepidophytes in the flora.

The specific name verrucosa instead of ficoides has been used because of the fact that Martin's name, which seems to be a good binomial, has a priority of several years over Sternberg's, although this fact is not generally observed. David White, however, has discussed this problem of nomenclature at considerable length and has adopted the name used here. It is therefore not necessary to go into the matter and is sufficient to state that White's opinion appears to be correct.

Occurrence: Bed 17 of Evans Peak section; bed 5 of Pennsylvania Mountain section; collected by J. H. Johnson, C. D. Hier, and C. B. Read. 


\section{EQUISETALES}

\section{CALAMARIACEAE}

Calamites sp.

There are several fragments of Calamites in the collections, but their preservation is so poor that it is impossible to identify them specifically. They are of the coarse, alternating-ribbed type, and it is possible that more than one species is represented. Their importance is slight, as they only bear out the material inference to be drawn from the Asterophyllites foliage that arborescent calamarians were present in the original flora.

Occurrence: Bed 17 of Evans Peak section; collected by J. H. Johnson, C. D. Hier, and C. B. Read.

\section{Asterophyllites longifolius (Sternberg) Brongniart?}

Plate 16, figure 8

Two specimens from locality 8049 represent a species of Asterophyllites very closely related to if not identical with Asterophyllites longifolius (Sternberg) Brongniart. ${ }^{10}$ In view of the insufficient and very fragmentary material, the name is used in this paper with a query.

The figure shows the general aspect of the best specimen, which is an incomplete whorl of leaves. The laminae are apparently rigid, and the under surface is finely longitudinally striate. In another specimen the leaves attain a length of 25 millimeters. A scarcely perceptible sheath unites the leaves at the base.

Asterophyllites longifolius (Sternberg) Brongniart has been completely discussed by White, ${ }^{11}$ and it is not necessary to dwell in detail upon this subject in the present paper.

In Europe Asterophyllites longifolius is a longranging form, being recorded from Westphalian to Permian. In North America it has previously been reported only in post-Pottsville strata. The Weber (?) plant beds are beyond any doubt Pottsville. This aparent discrepancy in range may be due to the present insufficient knowledge of American Carboniferous floras or to an erroneous identification based on the fragmentary material.

Occurrence: Bed 17 of Evans Peak section; collected by J. H. Johnson, C. D. Hier, and C. B. Read.

${ }^{10}$ Sternberg, G. K., Flora der Vorwelt, vol. 1, p. 29, pl. 58, fig. 1, 1820. Brongniart, Adolphe, Prodrome, p. 157 (159), 1828.

11 White, David, Fossil flora of the lower Coal Measures of Missouri : U.S. Geol. Survey Mon. 37, pp. 153-156, 1899.

\section{SPERMATOPHYTA}

\section{GYMNOSPERMAE}

CYCADOFILICALES

NEUROPTERIDEAE

\section{Neuropteris dluhoschi Stur}

Plate 17, figure 5

Neuropteris dluhoschi Stur, K.-k. geol. Reichsanstalt Abh., vol. 8, no. 2, p. 183 (289), pl. 11, fig. 9, 1877.

White, Geol. Soc. America Bull., vol. 4, p. 128, 1893.

Frond large, at least tripinnate. Penultimate pinnae flexuose, broadly lanceolate, the axis strong, longitudinally multistriate; ultimate pinnae borne alternately, linear-lanceolate with acute apices, the rachis small, striate similar to penultimate rachis; pinnules crowded, touching or slightly imbricate, at right angles to the axis or a little oblique with decurrent base, a little inflated, flexuose, lanceolate with acute, pointed, or narrowly rounded apices; broadest point below middle, base equilateral and cordate or more often inequilateral and attenuate below, midrib strong, marked by groove, extending nearly to apex before breaking up into numerous secondaries; secondary veins numerous, crowded, decurrent, arching rapidly to follow a nearly right angle course to margin, sometimes even arched backward, dichotomizing once or twice.

Neuropteris dluhoschi Stur is one of the transitional neuralethopterids which are so abundant in the Pottsville of this country. The figure shows a fragment of a penultimate pinna bearing two ultimate pinnae. It will be noted that the axis is large and longitudinally striate, although this last feature is not shown in the illustration. The alethopteridlike appearance of the pinnules is striking, but the mode of attachment by the midrib and directly adjacent tissue rather than by the whole breadth of the base definitely places the plant in Neuropteris. The somewhat linear, straplike pinnules have been slightly rolled at the margins, the shape being in reality more inflated. The midrib is deeply set in a heavy furrow and is strong to a point within a short distance of the apex. The secondary nervation is similar in many respects to that of Alethopteris, consisting of crowded, decurrent veins rapidly arching to a right-angle position and dichotomizing infrequently.

Neuropteris diuhoschi is comparable in external morphology with several species that are characteristic of the Pottsville formation and its equivalents in North America and in Europe. It is readily con- 
fused with Neuropteris schlehani Stur, ${ }^{12}$ as is attested by an examination of the figures and descriptions given by numerous European investigators. Neuropteris elrodi Lesquereux, which is possibly indistinguishable from $N$. schlehani, is perhaps the most closely related American species but can be distinguished by the broader pinnules with more rounded, obtuse apices and the shallower sinus marking the midrib. Neuropteris smithsii Lesquereux likewise exhibits many points of similarity with $N$. dluhoschi but in general is characterized by its shorter, more compact, quadrate pinnules with fine, arching veins.

Neuropteris pocahontas White ${ }^{13}$ and its varieties resemble Neuropteris dluhoschi but are readily separated by the form of the pinnules and by the open and flexuose venation. White has suggested that this species should be segregated into Neuro-callipteris rather than Neuro-alethopteris.

Neuropteris dluhoschi furnishes very reliable information concerning the age of the flora. It is typical of a subgenus which reached its maximum development in Pottsville time and which persisted into the Allegheny with only a few highly specialized representatives. The species mentioned above, which are almost certainly closely related to $N$. dluhoschi, are all of Pottsville age. In Europe this species has been noted in the Westphalian. The presence of $N$. dluhoschi Stur in the Weber (?) flora is therefore indicative of the Pottsville age of the basal portion of the formation.

\section{Neuropteris heterophylla Brongniart}

Plate 16, figure 7

Lithosmunda minor Scheuchzer, Herbarium diluvianum, $\mathrm{p}$. 15, pl. 4, fig. 3, 1709 .

Liud, Lithophylacii Britannici Iconographia, p. 12, pl. 4, fig. 189, 1760 .

Phytolithus (Osmundae regalis) Martin, Petrificata derbiensis, pl, 19, figs. 1-3, 1809

Filicites (Neuropteris) heterophyllus Brongniart, Classification des végétaux fossiles, p. 33, pl. 2, figs. 6a, 6b, 1822. Neuropteris heterophylla Brongniart, Prodrome, p. 53, 1828; Historie des végétaux fossiles, vol. 1, p. 243, pl. 71; pl. 72, fig. 2, 1829.

Several fragmentary specimens in the collections indicate beyond reasonable doubt that one of the Weber (?) elements is Neuropteris heterophylla as defined and figured by Brongniart. The Colorado material has been carefully compared with numerous authentic specimens from France and England which are in the Lacoe collection, with the result that no trustworthy difference of specific magnitude has been

\footnotetext{
12 Stur, D., Die Culm-Flora: K.-k. geol. Reichsanstalt Abh., Band 8, Heft 2, p. 183 (289), pl. 11, fig. 9, 1877

13 White, David, The stratigraphic succession of the fossil floras of the Pottsville formation in the southern anthracite coal field, $\mathrm{Pa}$.: U.S. Geol. Survey 20th Ann. Rept., pt. 2, pp. 888-893, pl. 188, figs. 2-5 ; pl. 189 , figs. 4 , 4a, 5, 5a, 5b ; pl. 150 , fig. 7 ; pl. 191 , figs. $1-5,1900$.
}

found. The lanceolate, acutely pointed pinnae and the flexuose pinnules becoming odontopteroid apically agree very well in the Westphalian and Evans Peak material.

The historical study of Neuropteris heterophylla Brongniart has indicated that there has been much confusion in the concepts of this and related forms. Several species have been described which are undoubtedly identical with $N$. heterophylla as it was understood by Brongniart. Likewise there are forms included in $N$. heterophylla which are certainly distinct. In the writer's opinion there is no question as to the validity of the species, however, despite statements to the contrary. ${ }^{14}$

In America a certain amount of confusion has resulted from Lesquereux's identification of Neuropteris ovata Hoffman as Neuropteris loschii Brongniart. It is generally admitted that $N$. loschii and $N$. heterophylla are identical, although $N$. ovata is quite distinct. As a result of this misidentification $N$. heterophylla has been reported in America as ranging up almost to the Permian, though as a matter of fact its occurrence is very rare and is restricted to strata of Pottsville age. $N$. heterophylla is definitely related to $N$. rarinervis, $N$. tenuifolia, $N$. flexuosa, and an undescribed species, $N$. tennesseeana Lesquereux MS., but can be separated, although this is accomplished only with difficulty in some cases.

Occurrence: Bed 17 of Evans Peak section; collected by J. H. Johnson, C. D. Hier, and C. B. Read.

\section{Neuropteris gigantea Sternberg?}

Under this name a few fragments that are not sufficiently well preserved to allow certain identification are here recorded. The pinnules are large, apparently broad-lanceolate with subparallel margins in the basal portion, and are truncate-cordate at the base. The nervation, though so indistinct that it is impossible to make out all the details, is more acute with reference to the poorly defined midrib than in the specimens figured by Sternberg ${ }^{15}$ or in specimens labeled "Neuropteris subfalcata" by Lesquereux ${ }^{16}$ and more recently identified with $N$. gigantea Sternberg by White. ${ }^{17}$ According to White the typical form of $N$. gigantea occurs only in the upper beds of the Pottsville group of the Appalachian region. There are forerunners, though, which extend well back toward the middle Pottsville, the limit of their range being

${ }^{14}$ Bolton, Edith, A critical study of certain species of the genus Neuropteris Brongniart: Linnean Soc. London Jour., Botany, vol. 47, p. $310,1926$.

${ }^{15}$ Sternberg, G. K., Flora der Vorwelt, vol. 1, p. 27, pl. 22, 1825 (Osmunda).

${ }^{16}$ Lesquereux, Leo, Description of the coal flora: 2d Pennsylvania Geol. Survey Rept. P, vol. 1, p. 102 ; atlas, pl. 13, figs. 5, 6, 1880.

${ }^{17}$ White, David, The stratigraphic succession of the fossil floras of the Pottsville formation in the southern anthracite coal field, Pa.: U.S. Geol. Survey 20th Ann. Rept., pt. 2, p. 895, 1900. 
unknown to the writer. Thus it is apparent that this species can afford little exact information as to the age of the beds, although it confirms the rough identification of the flora as Pottsville.

Occurrence: Bed 17, Evans Peak section; collected by J. H. Johnson, C. D. Hier, and C. B. Read.

\section{Family SPHENOPTERIDEAE}

\section{Sphenopteris cf. S. microcarpa Lesquereux}

Plate 17 , figures 6,7

Frond polypinnate. Penultimate pinnae linearlanceolate (?), the rachides sinuose, strong, irregularly rugose. Ultimate pinnae distant, alternate, attached to penultimate rachis at peaks of outward-bulging flexes at open angles, short, lanceolate, the axes weak, broadly winged. Pinnules opposite or subopposite, distant, attached by a very short stalk varying from narrow and distinct to wide and indistinct, ovate, decurrent, varying in size and shape according to position on rachis; lower pinnules two or chiefly three, lobed distally, these separated by sinuses extending about halfway to base, directed outward and slightly forward, acutely rounded apically; occasionally inferior basal pinnule entire and reniform; distal pinnules more nearly linear, entire or often bilobed, the stalks scarcely distinguishable; terminal pinnule small, bilobed or trilobed, these slightly swollen. Laminae formed of apparently tough coriaceous tissue. Nervation poorly preserved, the midrib decurrent, giving off laterals to supply each lobe, these continuing to distal margin.

The single fragment of this species fails to show any details which conclusively establish its taxonomic position. Figure 7 reproduces the specimen. The most conspicuous feature is the angularly sinuose rachis. This is rather thick and appears to have been very woody. It is rugose but without any very definite pattern. The ultimate pinnae are distant and appear to have been rigid.

In figure 6 the same specimen is shown enlarged three times. The pinnule outline is ovate or broadly cuneate but is modified by the presence of lobes in the apical portion of the lamina. Although the pinnules are generally distant, they tend to become crowded apically. They are seated by very short stalks of varying width on the alate rachis.

This plant resembles Sphenopteris microcarpa Lesquereux ${ }^{18}$ in numerous respects but fails to show the prominent denticulate pinnule margins which characterize that species. The pinnules of $S$. microcarpa are usually of different proportions, being commonly longer and narrower. Although it is possible that

\footnotetext{
${ }^{18}$ Lesquereux, Leo, op. cit., pp. 280-281, pl. 47, figs. 2-2b. $59021-34-2$
}

the range of variation in $S$. microcarpa Lesquereux includes the present specimen, the identification given here is only provisional.

The trilobate pinnules suggest Sphenopteris asplenioides Sternberg in certain of its dissected variants, but the proportions are different. There is no indication of the thick lamina which characterized that species.

Renaultia gracilis (Brongniart) Zeiller ${ }^{19}$ likewise is similar to the plant here discussed. The trilobed pinnules developed in some individuals, the sinuose rachis, the distant pinnules, and the texture agree well with the Colorado specimen. However, $R$. gracilis is more delicate, and the pinnae are more triangular in outline.

Sphenopteris footneri Marrat ${ }^{20}$ is related to Sphenopteris cf. S. microcarpa but is a more compact type with crowded pinnules and broadly triangular pinnae. It is with difficulty separated from Sphenopteris gracilis.

Sphenopteris microcarpa Lesquereux appears to be restricted to the upper part of the Lykens coal group and its equivalents in the Appalachian region. In consequence the presence in the Weber(?) of a species which is closely related if not identical strongly suggests a similar age.

Occurrence: Bed 17 of Evans Peak section; collected by J. H. Johnson, C. D. Hier, and C. B. Read.

\section{Sphenopteris asplenioides Sternberg}

Sphenopteris asplenioides Sternberg, Flora der Vorwelt, vol. 1, p. 16,1825 ; vol. 2 , pts. 5 and 6, p. $62,1833$.

White, U.S. Geol. Survey 20th Ann. Rept., pt. 2, p. 879, 1900.

Sphenopteris hoeningshausi Brongniart, Prodrome, p. 51, 1828.

Fragmentary remains, "ghost" impressions, from locality 8050 are identical with Sphenopteris asplenioides Sternberg (Sphenopteris hoeringshausii Brongniart)..$^{21}$ No evidence of any variation which might serve to characterize this species in its Cordilleran distribution has been noted in this material, although elsewhere ${ }^{22}$ there are known to occur very small forms which may deserve varietal rank.

${ }_{19}$ Brongniart, Adolphe, Histoire des végétaux fossiles, vol. 1, p. 197 pl. 54, fig. 2, 1829. Zeiller, R., Fructifications des fougères du terrain pl. 54, lg. 2, 18. 1883. houiller: Annales sci. nat., Kidston, Robert, Fossil plants of the Carboniferous rocks : Geol. Surve Great Britain Mem., Paleontology, vol. 2, pp. 310-313, pl. 79, figs. 1-5, 1923.

${ }^{20}$ Marrat, F. P., On the fossil ferns in the Ravenhead collection: Iiverpol Proc., 1871-72, vol. 2, p. 101, pl. 8, figs. 2, 3, 1872 Liverpool Geol. Soc. Survey Kidston, Robert, Fossil plants of Paleontology, vol. 2, pp. 117-120, pl. 24, figs. 1, 1a, 1b, 2-6; pl 25, fig. 5, 1923.

${ }_{21}$ See White, David, op. cit., p. 879 , for explanation of this nomenclature.

22 The collection referred to here was made by David White and the weber(?) shales in the Arkansas River Canyon near Wellsville springs, Colo. 
As Sphenopteris asplenioides Sternberg has been described by several writers, ${ }^{23}$ a discussion of its taxonomic characters is not necessary in this paper. It is sufficient to point out that this species is important in indicating the age of the beds from whch it was collected. In the Appalachian region it is characteristic of the Pottsville group and is not known to range higher. Therefore the occurrence of $S$. asplenioides Sternberg in the lower part of the Weber(?) formation may be taken as strong evidence of the early Pennsylvanian age of the basal portion of the section.

Occurrence: Bed 5 of Pennsylvania Mountain section; collected by J. H. Johnson, C. D. Hier, and C. B. Read.

Sphenopteris cheathami (Lesquereux) Read, n. comb.

Plate 16 , figure 5 , d; plate 17 , figures $1-4$

Eremopteris cheathami Lesquereux, 2d Pennsylvania Geol Survey Rept. P, vol. 3, pp. $770,853,889,919$, pl. 104, figs. $2-4,1884$.

White, U.S. Geol. Survey 20th Ann. Rept., pt. 2, pp. 870 871,1900 .

Fronds of medium size, probably broad-lanceolate or triangular, bipinnate or tripinnate, rachis flexuose, small; primary pinnae lanceolate with acutely rounded apices, the axis narrow, irregularly rugose, and flexuose. Secondary pinnae distant, alternate, at right or slightly acute angles to the rachis, linear-lanceolate, the margins subparallel and tapering gradually from the base to the narrowly rounded apex, the axis small, sulcate above, slightly and irregularly crenulate both longitudinally and transversely. Pinnules alternate or subopposite, crowded in distal portions of the frond, broadly cuneate, elongate-oval, or oval, decurrent, often bilobed or trilobed, the lobes never cleft below the middle of the pinnule, apices bluntly rounded, commonly irregularly crenate, serrate, or erose, lateral margins entire; venation indistinct, basal veins apparently dichotomizing several times while crossing lamina to distal margin; each lobe plurinerved; pinnules, connected by narrow rachial wings, which become suppressed in proximal regions.

Sphenopteris cheathami (Lesquereux) is abundant at locality 8049 , where the most productive parting is littered with impressions of pinnules and fragments of pinnae. Figure 4 reproduces one of the largest specimens in the collection. It will be seen that the frond is polypinnate and has a lax habit. The rachides of the pinnae are noticeably slender in proportion to the size of the plant. The cuneate, usually lobed pinnules, are conspicuous.

Figure 1 illustrates fragmentary pinnae which plainly demonstrate the nature of the pinnules. These

${ }^{23}$ Sternberg, Kaspar, Flora der Vorwelt, vol. 1, p. 16, 1925. Brongniart, Adolphe, Prodrome, p. 60 (51), 1828; Histoire des végétaux fossiles, vol. 1, p. 199, pl. 52, 1829. Kidston, Robert, Fossil plants of the Carboniferous rocks: Geol. Survey Great Britain Mem., Paleontology, vol. 2, p. 115, pl. 23, figs. 6, 6a, 1923. are chiefly ovate-cuneate and are somewhat irregularly serrate distally. Figure 3 shows another fragment from the apex of a large pinna. It will be remarked that in general aspect the pinnules are unlike those of figure 1. These figures may be taken to indicate something of the range of variation.

Figure 2 is an enlarged view of the specimens shown in figure 1 and shows some of the details of pinnule arrangement, shape, and nervation. The bilobed and trilobed compact pinnules seated decurrently on the rachis are connected by narrow axial wings.

This species is identical with Lesquereux's Eremopteris cheathami. ${ }^{24}$ The Colorado plant is a somewhat larger type than that prevalent in the Pottsville, although occasional specimens are met with which are fully as robust.

Lesquereux's concept of the genus Eremopteris Schimper was an extremely broad one, as is attested by his insertion of the species here discussed in that genus. His definition, "Upper part of the fronds dichotomous; pinnae open or oblique, irregularly pinnatifid; laciniae long, obovate or wedge-form, the lower ones deeply cut, ${ }^{25}$ obviously includes a much larger and heterogeneous assemblage than is now admitted in Eremopteris. . The recommendation of White in 1899 that Eremopteris should be restricted to a small group of plants which conform strictly to $E$. artemisalefolia (Sternberg) Schimper is more in keeping with current taxonomic practice and is adopted in this paper. A less rigid usage deprives the genus of its significance. Certainly the "E. cheathami" of Lesquereux is far removed from the typical form of the genus referred to above and is closely related in its general structure to that group of sphenopterids typified by Sphenopteris obtusitoba.

Sphenopteris cheathami is distinct in America and cannot be readily confused with European species. It is perhaps related to certain undescribed Pottsville species, but a comparison with these cannot be made here. Sphenopteris valida Dawson ${ }^{26}$ resembles this plant in some respects but not so closely as to cause confusion. Sphenopteris sauveuri Crépin ${ }^{27}$ is also of the same general stock as $S$. cheathami but differs in the more lax appearance and more deeply lobed pinnules.

Sphenopteris cheathami (Lesquereux) is recorded by White ${ }^{28}$ from the lower, intermediate, and upper

${ }^{24}$ Lesquereux, Leo, op. cit., pp. 770-771, pl. 94, figs. 2-4.

${ }^{25}$ Lesquereux, Leo, Description of the coal fiora of the Carboniferous formation in Pennsylvania: Pennsylvania Second Geol. Survey Rept. P, vol. 1, p. 292, 1880.

${ }^{26}$ Stopes, M. C., The "Fern Ledges" Carboniferous flora of St. John, N.B. : Canada Geol. Survey Mem. 41, pp. 34-36, pl. 9, fig. 21 ; pl. 10, figs. 22-23, 17914.

${ }^{27}$ Crépin, François, Observations sur quelques Sphenopteris et sur les côtes des Calamites: Soc. roy. bot. Belgique Bull., vol. 19, p. 54, 1880 .

${ }^{28}$ White, David, The stratigraphic succession of the fossil floras of the Pottsville formation in the southern anthracite coal field, Pa.: U.S. Geol. Survey 20th Ann. Rept., pt. 2, pp. 780-781, 1900. 
parts of the Lykens coal group of the Pottsville formation of eastern Pennsylvania. Its occurrence in lower part of the Weber(?) furnishes excellent evidence of the Pottsville age of at least that part of the formation.

Occurrence: Bed 17 of Evans Peak section; collected by J. H. Johnson, C. D. Hier, and C. B. Read.

\section{Diplotmema patentissima (Ettingshausen) Stur}

Plate 16, figure 3

Hymenophyllites paten issimus Ettingshausen, K. Akad. Wiss. Wien, Math.-naturwiss. Cl., Denkschr., Band 25, p. 26, fig. 13 ; pl. 7 , fig. 4,1865 .

sphenopteris (Hymenophyllites) patentissima Schimper, Traité de paléontologie végétale, vol. 1, p. 407, 1869.

Rhodea patentissima Stur, K.-k. geol. Reichsanstalt Abh., Band 8, Heft 1, p. 36, pl. 9, figs. 1-9, 1875.

Renault, Cours de botanique fossile, vol. 3, p. 193, pl. 33, fig. $12,1883$.

Hoffman and Rhyba, Leitpflanzen, p. 43, pl. 6, fig. 1, 1899. Diplotmema patentissima Stur, op. cit., Heft 2, p. 234, 1877.

Kidston, Geol. Survey Great Britain Mem., Paleontology, vol. 2 , pt. 3 , pp. $253-254$, pl. 54 , figs. $5-6$; pl. 56, figs. 4, 4a, 1923.

Sphenopteris patentissima Schimper, in Zittel, Handbuch der Paläontologie, Abt. 2, p. 108, fig. 76, 1890.

White, U.S. Geol. Survey 20th Ann. Rept., pt. 2, p. 880 , pl. 188, fig. 1, 1900.

Frond and primary pinnae unknown in the present suite of specimens. Pinnules alternate, somewhat imbricate, open rhomboidal-rounded in outline but modified by deep dissection into linear lobes; the larger pinnules divided into 8 to 12 narrow, digitate segments, the smaller, more distant ones often reduced to a simple or once dichotomous lamia, all gradations between these extremes being found in the intermediate portions of the pinna. Segments divergent, margins parallel or nearly so, gradually converging upward to a rounded apex. A single vein which is decurrent on the rachis enters each pinnule and forks to supply each lobe with one nerville. Epidermis scaly, the scales parallel to veins and tending to obscure them. Texture thin, coriaceous (?).

Several fragments in the collections clearly indi cate the presence of a diplotmemoid plant with the essential features of Diplotmema patentissima (Ettingshausen) Stur. The figure illustrates the nature of the plant. The pinnules are lax and are cleft into numerous linear lobes, giving the lamina a digitate appearance. These lobes are uninerved and are coverad with small scaly protuberances which are oriented parallel to the veins and tend to obscure them. This feature was pointed out by White ${ }^{29}$ as being very characteristic of the species. It is more strongly emphasized in the Colorado material than in specimens from the Pottsville of the Appalachian region and suggests that the plant may be distinct. It does not

\footnotetext{
${ }^{29}$ White, David, op. cit., p. 880.
}

seem advisable to describe a new species or variety on such obscure fragments, however, so it has been retained in Stur's species, from which it can be segregated if additional material makes it necessary.

In several respects the Weber(?) plant resembles Sphenopteris furcata Brongniart, ${ }^{30}$ Sphenopteris royi Lesquereux, ${ }^{31}$ Rhodea smithii Kidston, ${ }^{32}$ and Zeilleria moravica (Ettingshausen) Bureau, ${ }^{33}$ but it can be separated by the decidedly lax and spreading pinnules. S. furcata is more compact, and the pinnules are usually less deeply incised and are chiefly sessile on the pinna axis. In $S$. royi the ultimate divisions of the pinnules are more acute than in Diplotmema patentissima, and the latter is distinguished from $Z$. moravica by the larger and laxer pinnules.

Diplotmema patentissima occurs, according to White, ${ }^{34}$ in "the lower portions of the very thick sections of the Pottsville series in the' Virginia, Tennessee, and Alabama regions, as well as in the southern anthracite field of Pennsylvania." In other words, it is a typical Pottsville species, and its presence may be taken as indicative of the Pottsville age of the Weber(?) beds from which it was collected.

Occurrence: Bed 17 of Evans Peak section; collected by J. H. Johnson, C. D. Hier, and C. B. Read.

\section{Genus ADIANTITES Goeppert, emended}

Adiantites Goeppert (part), Systema filicium fossilium, pp. $173,216,1836$.

Adiantides Schimper (part), Traité de paléontologie végétale, vol. 1, p. 424, 1869.

"Adiantites" is used as a generic designation which includes types of fossil plants characterized by cuneate or wedge-shaped pinnules, sessile or attached to the rachis by a foot stalk. The pinnules are usually entire or slightly lobed but occasionally may be deeply incised. The venation consists of several radiating and frequently dichotomizing nerves, there being no definite central strand. The plants were often rather large and bore rank foliage. Adiantites is to be regarded as a form genus rather than a natural one. Some, at least, of the plants falling within it are cycadofilic. This has been proved by White ${ }^{35}$ for Aneimites (Wardia) fertilis, a form very similar to some species of Adiantites.

The validity of the generic name "Adiantites" is questionable, because Goeppert first used it for Ginkgo

${ }^{30}$ Brongniart, Adolphe, Prodrome, p. 59 (50), 1828 (nomen nudum) ; Histoire des végétaux fossiles, vol. 1, p. 179, pl. 49, figs. 4-5, 1829.

${ }^{31}$ Lesquereux, Leo, Description of the coal flora: 2d Pennsylvania Geol. Survey Rept. P, vol. 3, p. 768, pl. 104, figs. 7-10, 1884.

${ }^{32}$ Kidston, Robert, Fossil plants of the Carboniferous rocks: Geol. Survey Great Britain Mem., Paleontology, vol. 2, p. 226, pl. 56, figs, $1-2 ;$ pl. 57, figs. $2-3,1923$.

${ }^{33}$ Bureau, Edouard and Louis, Excursion du 7 septembre à Oudan, Ancenis, Mésongen, Cap-Chaux, Mouzeil: Soc. géol. France Bull., sér. 4 , vol. 8 , p. $653,1908$.

${ }^{34}$ White, David, op. cit., p. 880 .

${ }^{35}$ White, David, The seeds of Aneimites: Smithsonian Misc. Coll., vol. 47 , pt. 3 , pp. $322-331$, pls. $47-48,1904$. 
digitata, a Jurassic plant. However, long usage as the generic designation for plants of the type described above has made it desirable to retain the genus in the emended sense.

\section{Adiantites rockymontanus Read, n.sp.}

Plate 18, figures 5, 6

Fronds and pinnae unknown, probably large. Pinnules of medium size, 12 to 15 millimeters long and 6 to 8 millimeters broad, cuneate, the apices rounded and shallowly trilobed or slightly bilobed and giving the lamina an obcordate outline; sides straight or slightly convex; base wedge-shaped, narrow, attenuate, probably decurrent, 8 to 11 millimeters long and 2 to 3 millimeters wide. Venation regularly dichotomous, a single vein passing into the base of the pinnule, bifurcating immediately to form branches which by frequent dichotomy supply the pinnule with numerous slightly arched, closely spaced veins passing to the distal margin, where they are spaced 3 to the millimeter. Texture markedly coriaceous, the veins prominent and the surface corrugated.

Adiantites rockymontanus is one.of the most interesting species in the Evans Peak collection and provides an element of speculation concerning the age of the beds. Figure 5 reproduces a complete and wellpreserved pinnule of the plant. Its distinctly cuneate outline and the corrugated appearance are very conspicuous characters. The apex is trilobed, although not conspicuously so. Basally the lamina tapers into a broad and heavy stalk, the length of which cannot be determined.

The details of venation are well shown in figure 6 , which is an enlarged view of one of the pinnules. The frequent dichotomies are well shown, and the peculiar corrugated surface is very plain.

Adiantites rockymontanus appears to be genetically related to Adiantites adiantoides (Lindley and Hutton). ${ }^{36}$ They are not to be confused, however, the pinnules of the Colorado form being narrower and developing a trilobed, narrowly obtuse apex of a type not figured or described in $A$. adiantoides. Also $A$. rockymontanus has more crowded veins, and the pinnules apparently are thicker and harder in texture. The corrugated appearance of the pinnules is very distinctive. The elongate base, which suggests a decurrent attachment on the rachis, is another characteristic at variance in $A$. rockymontanus and $A$. adiantoides, the latter developing a short pinnule base which is slightly, if at all, decurrent.

The possibility of an affiliation of Adiantites rockymontanus with species of the genus Aneimites has

\footnotetext{
${ }^{36}$ Lindley, John, and Hutton, William, Fossil flora of Great Britain, vol. 2, p. 91, pl. 115, 1834 (Sphenopiteris adiantoides). Kidston, Rob ert, Fossil plants of the Carboniferous rocks: Geol. Survey Great Britain Mem., Paleontology, vol. 2, pp. 190-191, pl. 45, figs. 3-4a; pl. 4.6, figs. 1-2, 1923.
}

been considered carefully. To the Pocono species, Aneimites spectabilis White ms., there is marked similarity. In view of the questionable status of "Aneimites" as a generic name it seems best at the present time to assign this species to Goeppert's genus in its emended sense.

As has already been stated, Adiantites rockymontanus has a critical bearing on the age of the plant beds. It is strongly suggestive of Mississippian types, particularly Aneimites spectabilis, and suggests caution in assigning the age of the beds to a position very high in the Pennsylvanian. On the other hand, its affinity with Adiantites adiantoides, which is of Westphalian and Lanarkian age, furnishes ample justification for the assignment of Pottsville age to the enclosing beds.

Occurrence: Bed 17 of Evans Peak section; collected by J. H. Johnson, C. D. Hier, and C. B. Read.

\section{CORDAITALES}

Cordaites sp.

Plate 16, figure 5b

The material of Cordaites which has so far been obtained from Evans Peak and Pennsylvania Moun-. tain is limited to several incomplete leaves of what is probably a new species. In figure $5 \mathrm{~b}$ such a fragment is illustrated. The leaf is rather narrow and is of an unknown length. The venation is similar to that of Cordaites robbii Dawson ${ }^{37}$ but is somewhat: finer. The coarse nerves, which are usually 3 to the millimeter, alternate with indistinct fine nerves. Although it is possible that the specimen figured, as well as others in the collection, may be identical with Cordaites robbii, the evidence is not convincing to the writer. Cordaites robbii is usually a larger, broader type than the Weber(?) plant and, as has been stated. above, differs somewhat in venation. Specific identification has been deferred until additional material. can be obtained.

Oscurrence: Bed 17 of Evans Peak section; collected by; J. H. Johnson, C. D. Hier, and C. B. Read.

\section{Cordaicarpon sp.}

Plate 16, figure 6

Seed very nearly flat, ovate, $11+$ millimeters long and about 14 millimeters broad, broadly winged; seed proper fusiform, elongated with longitudinal axis: of fructification, 4 to 5 millimeters long and 2 millimeters broad, located centrally and entirely surrounded by wing. This wing nearly circular, 6 to 8 : millimeters in width, becoming slightly broader near

${ }^{37}$ Dawson, J. W., On the flora of the Devonian period in northeastern America: Geol. Soc. London Quart. Jour., vol. 18, p. 316, pl. 14, figs 31a-c, 1862 ; Acadian geology, 2d ed., p. 544, fig. 190, 1868. 
the base, not entirely preserved but apparently entire and rounded.

This species, which is represented by a single specimen, is almost certainly new. In view of the poor preservation, which has prevented a detailed description, it has been considered best to list the seed simply as Cordaicarpon sp. The most conspicuous feature of the seed is the nearly circular form of the wing, illustrated in figure 6. It is apparent that this is one of the large, wide-winged species of the type of $\mathrm{Cor}$ daicarpon newberryi ${ }^{38}$ C. phillipsi, ${ }^{39}$ and $C$. baileyi. ${ }^{40}$ It is, however, distinct from any which the writer has so far observed. According to White this group is particularly characteristic of the upper Lykens or Sewanee coal zone of the Pottsville group and hence furnishes evidence in favor of the assumption that the flora is Pottsville in age.

Occurrence: Bed 17 of Evans Peak section; collected by J. H. Johnson, C. D. Hier, and C. B. Read.

\section{Cordaianthus sp.}

There are two poorly preserved fragments of $\mathrm{Cor}$ daianthus in the collection from locality 8049 which cannot be specifically determined. The better specimen has a heavy tapering axis, the surficial features of which are nearly obliterated. It bears numerous crowded, fertile branches subtended by large sterile bracts. The strobili are of medium size and are nearly sessile on the axis. Their characteristics cannot be established with the material at hand. In general aspect there is a resemblance to Cordaianthus bacoifer Grand'Eury, ${ }^{41}$ a group to which it probably belongs. It is not, however, specifically identical with that fossil, differing in the broader axis and the larger "spike" of strobili. Any further comparison seems unnecessary with the poor material now representing the form.

Occurrence: Bed 17 of Evans Peak section; collected by J. H. Johnson and C. D. Hier.

\section{POSITION UNCERTAIN •}

\section{PALAEOPHYLLALES}

Trichopitys whitei Read

Plate 16, figure 5a; plate 18, figures 1, 4

Trichopitys whitei Read, Washington Acad. Sci. Jour., vol. 23, pp. 461-463, 1933.

Leaves more than 80 millimeters long and 80 millimeters wide, obtriangular, deeply dissected into numerous linear lobes; narrow at base but expanding rapidly to bifurcate into subequal lobes about 2 milli-

\footnotetext{
${ }^{38}$ Andrews, E. B., Descriptions of fossil plants from the coal measures of Ohio: Ohio Geol. Survey Rept. 2, pt. 2, Paleontology, p. 425, pl. 46, fig. 2, 1875 .

${ }^{39}$ White, David, op. cit., p. 907.

${ }^{40}$ Dawson, J. W., Acadian geology, 2d ed., p. 554, fig. 194 D, 1868.

41 Grand'Eury, F. C., Flore carbonifère du département de la Loire, pp. 230-231, pl. 26, 1877.
}

meters in breadth, these soon forking again into two unequal lobes which bifurcate at least once or twice, the apices not being preserved intact, these equally dichotomous, forking at an angle of about $30^{\circ}$, contracting gradually to acute terminations. Nervation consisting of two basal veins dichotomizing to supply the primary lobes with three or four veins, which further dichotomize to supply subterminal and terminal lobes with one to three veins, all of these large, prominent, spaced evenly on lamina. Texture apparently coriaceous; base and lobes thick and rounded in cross section.

The reference of the peculiar leaves shown in figure 5a to Trichopitys is based on the facts concerning this genus which have been accumulated by Saporta, ${ }^{+2}$ Renault, ${ }^{43}$ Feistmantel, ${ }^{44}$ and others. The actual discrimination between Trichopitys and Dicranophyllum is extremely difficult when sterile leaves only are present. In fact, when the plant described here was first examined it was called Dicranophyllum, and on very good grounds. If the fructifications and fertile appendages are disregarded, as all the Colorado material is vegetative, the distinction between these genera lies in the greater symmetry, more equal dichotomy, smaller size, and, in general, greater rigidity of Dicranophyllum, together with the more crowded, spirally arranged leaves. This last criterion is of slight value in general practice, owing to the usual occurrence of the remains as detached laminae.

Plate 16, figure 5, is a photograph of a specimen of shale on which two specimens of Trichopitys whitei are exposed. Numerous comminuted remains of this and other plants are likewise to be seen. The small size of Trichopitys whitei is at once apparent. Most of the species that have previously been placed in this genus are much larger, to judge from published fig. ures. Another feature of importance is the apparently short base. The matrix and nature of preservation of the leaves do not allow a complete uncovering of the specimens, but the bases cannot be very attenuate. This is also in contrast to many representatives of the genus.

Plate 18, figure 1 , shows one of the specimens on the slab at a magnification of 3 diameters. The plurinerved, dichotomous venation is indistinctly shown, and the fanlike expansion of the blade is also apparent, as are the numerous dichotomies.

In figure 4, plate 18, there is shown a fragment of a leaf in which the more distal portions of a lamina are exposed. It will be seen that the apices are narrowing to acute terminations.

42 Saporta, Gaston de, Sur la découverte de deux types nouveaux de conifères dans les schistes permiens de Lodève: Compt. Rend., vol. 80 , p. 1020,1875 .

${ }^{43}$ Renault, B., Cours de botanique fossile fait au Musée d'histoire naturelle, vol. 4 , pp. $64-65,1885$.

44 Feistmantel, Otakar, Uhenosne Útvary V Tasmanii, p. 113, 1890. 
Trichopitys whitei is distinct from any other species that have come to the writer's observation. Trichopitys millerensis B. Renault ${ }^{45}$ is comparable but differs in its smaller size, greater laxity, and details of venation. Trichopitys johnstoni Feistmantel ${ }^{46}$ is similar in size but has a much longer base and a narrower, more regularly dichotomous blade.

As this is the first record of Trichopitys in North America, it is desirable to summarize the opinions that have been expressed concerning the affinities of this peculiar genus. Trichopitys has usually been placed in the Ginkgoales, the basis for this assignment being found in the similarity of the leaves to those of the Mesozoic Crekanowstia. The criterion of leaf form is not always exact, and it is felt that there is not sufficient justification in this case for the inclusion. In describing Trichopitys heteromorpha Saporta, Zeiller ${ }^{47}$ says :

La même espèce a offert, à l'aisselle des feuilles, des axes munis de courts ramules latéraux dont chacun se termine par une graine ovoïde; la valeur morphologique de ces axes reste malheureusement indécise, bien qu'il semble naturel de voir en eux des organes foliares transformés.

These fructifications, representing either seeds or megaspores and associated tissues, occur, as Zeiller states, in the axils of leaves, if it is possible to judge from the figures. They are perhaps comparable to abnormalities that have been observed in the ovulate shoots of Ginkgo biloba, although this comparison is far-fetched.

A rather puzzling situation is introduced by Kiltorkensia devonica Johnson. This plant, which combines the characters of Trichopitys and Ginkgophyllum into what is apparently a single dimorphic, compound leaf, is almost surely a pteridosperm..$^{48}$ The author of the genus was of the opinion that it was an ancestral ginkgoaceous stock, but this opinion is scarcely tenable. The Trichopitys type of leaflet which is developed in this plant is a clear demonstration of gross morphologic similarity in widely separated stocks. The occurrence of detached leaves of both Trichopitys Saporta and Dactylophyllum in the Weber (?) collections has brought up the question whether these should be placed in two distinct genera or in a single species under the heading Kiltorkensia. The former stand has been taken on the ground that the two have not been observed in connection and that Trichopitys and Ginkgophyllum are in usually distinct genera, al-

\footnotetext{
${ }^{45}$ Renault, B., Bassin houiller et permien d'Autun et Epinac, atlas, pl. 82 , fig. 2,1893 ; text, p. $378,1896$.

${ }^{46}$ Feistmantel, Otakar, Uhenosné utvary V Tasmanii, p. 113, pl. 10 , figs. 4-5, 1890 .

47 Zeiller, C. R., Eléments de paléobotanique, p. 254, text.fig. 182, 1900.

${ }^{48}$ Johnson, Thomas, Spermolithus devonicus, gen. et sp. nov., and other pteridosperms from the Upper Devonian beds at Kiltorkan: Roy. Dublin Soc. Sci. Proc., new ser., vol. 15, no. 23, pp. 249-251, 1917. See also Seward, A. C., Fossil plants, vol. 4 , p. $88,1919$.
}

though the strength of the alternative stand cannot be denied.

There can be no doubt that the relationships of Trichopitys are obscure. Therefore the group name "Palaeophyllales" ${ }^{49}$ has been adopted, as it is noncommittal and implies no relationships.

The geologic range of Trichopitys is not exactly known at present. It has a sporadic occurrence in the Carboniferous and Permian and apparently ranges into the lower Mesozoic.

Occurrence: Bed 17 of Evans Peak section; collected by J. H. Johnson and C. D. Hier.

\section{Genus DACTYLOPHYLLUM Read, n. gen.}

Plate 18, figures 2, 3

"Dactylophyllum" is the name proposed for a very unusual type of leaf which was collected at locality 8050. The exact affinities of the plant, figures of which are here given, are a matter of no little interest and are highly problematic.

The leaf of the genotype, Dactylophyllum johnsoni, which is described below, is a digitate type, in outline not unlike certain Mesozoic species of Baiera. The venation, on the other hand, departs from Baiera in being much simpler and lacks the strong marginal strands that characterize most of the accepted ginkgoaceous leaves. The generic characters are as follows :

Leaf small, obtriangular, dissected into similar lobes, the base contracted into a flabby petiole(?) of unknown length, primary lobes dichotomous several times, the ultimate lobes linear and straplike. Nervation simple, two veins at the base giving rise to primary lobe venation by one or two regular dichotomies and giving rise to the venation of the lobes of the next higher order by further dichotomies just below each bifurcation of the lamina. Ultimate lobes with two to four veins. No distinct marginal veins of the type characteristic of Ginkgo observable.

Although Dactylophyllum is very similar in aspect to Baiera, in the writer's opinion its affinities probably do not lie with the Ginkgoales. A number of genera tentatively referred to the Ginkgoales have been described from the Paleozoic. Among these are Ginkgophyllum, Trichopitys, Dicranophyllum, Psygmophyllum, and Kiltorkensia. Without discussing the merits of these forms as putative Ginkgoales, it suffices to say that Dactylophyllum is distinctly different from any of them, although it approaches Ginkgophyllum and Kiltorkensia in certain respects. Its affinities may lie in the direction of the Pteridospermae, but this is

${ }^{49}$ Arber, E. A. N., On Psygmophyllum majus sp. nov. from the Lower Carboniferous rocks of Newfoundland, together with a revision of the genus and remarks on its affinities: Linnean Soc. London Trans., vol.
7 , pt. 18, p. 405,1912 . 
problematic. For the present the writer prefers to assign the genus to Arber's Palaeophyllales, which is a noncommittal order erected for sucb forms.

\section{Dactylophyllum johnsoni Read, n. sp.}

Plate 18, figures 2, 3

Leaf small, obtriangular, deeply cleft into two primary deltoid lobes; these further cleft into linear, straplike segments which are truncate or obtusely rounded apically and developed by slightly irregular dichotomy. Base somewhat attenuate and narrow. Venation at base of two (?) distinct veins, each of which furnishes the supply of one of the primary lobes and by dichotomy below the medial cleft gives rise to plurinerved ( 2 or 4 ) lobe bases; repeated dichotomy below each bifurcation of the lamina resulting in binerved or quadrinerved ultimate lobes. Intermittent dichotomies rare. Texture thin.

In figure 3 the general aspect of Dactylophyllum johnsoni is shown. This recalls numerous Mesozoic species of Baiera and in particular Baiera gracilis (Bean) Bunbury. The leaf is small, obtriangular, and deeply dissected into linear lobes. Basally it is contracted into a narrow attenuation. It is not clear whether this represents a broad-winged petiole or simply the base of the leaf.

Figure 2 represents the same leaf at a magnification of 3 times. The lobes, it will be noted, are dichotomous, although somewhat irregularly so. The venation is indistinctly shown. Two veins are present at the base and give rise to the venation of the two primary lobes. As these pass to the distal margin they dichotomize below each bifurcation of the leaf and occasionally in between, as the ultimate divisions may carry four veinlets.

There is considerable support for the argument that the Ginkgoales were present in Paleozoic time. Such genera as Psygmophyllum, ${ }^{50}$ Ginkgophyllum, ${ }^{51}$ Baiera, ${ }^{52}$ Glottophyllum, ${ }^{53}$ Nephropteris, ${ }^{53}$ Rhipidop-

50 Schimper, W. P., Traité de paléontologie végétale, vol. 2, p. 192, 1870 .

${ }^{51}$ Saporta, Gaston de, Sur la découverte de deux types nouveaux de conifères dans les schistes permiens de Lodève: Compt. Rend., vol. 80, p. 1017,1875 .

52 Braun, C. F. W., Beiträge zur Petrefactenkunde Bayreuth, Heft 6 , p. $20,1843$.

${ }_{53}$ Zalessky, M. D., Plants from the coal-bearing deposits of Sudzenka, Siberia: Soc. nat. Oural Bull., pt. 4, p. 28, 1912 sis, ${ }^{54}$ Trichopitys ${ }^{55}$ and Dicranophyllum ${ }^{56}$ are held by some investigators to furnish positive proof of the existence of this order at an early date. However, there are not sufficient data to prove positively the systematic position of all these genera. Seward, ${ }^{57}$ in commenting on the situation, writes that "several Paleozoic genera *** have been assigned to the Ginkgoales on evidence which in most cases is wholly inadequate."

The discovery in the Upper Devonian grits of Ireland of slender forked leaflets similar to the leaves of Trichopitys or Dicranophyllum attached to a rachis also giving off "Psygmophyllum" leaflets ${ }^{58}$ has an important bearing on the present case. The plant, Kittorkensia devonica Johnson, is regarded by Johnson as an ancestral ginkgoaceous stock, but it is more probably a pteridosperm with polymorphic pinnules. It is not unlikely that other Paleozoic Ginkgoales have similar affinities. Both Trichopitys and Dactylophyllum occur in the Weber(?) beds at the same locality, so it is possible that they represent a single species allied to $K$. devonica.

On the other hand, if Dactylophyllum johnsoni is actually a primitive representative of the Ginkgoales it is important in being an old record of a genus that was common in the Mesozoic. There are species of Psygmophyllum which antedate this, but they are much more open to question as regards their affinities. Dactylophyllum johnsoni does not allow careful comparison with the occasional species of Baiera from the Permian. Both Baiera raymondi Renault ${ }^{59}$ and Baiera virginiana Fontaine and White ${ }^{60}$ are distinct. Its most striking resemblance is to a small leaf of Baiera gracilis (Bean) Bunbury, but this is not close.

Occurrence: Bed 17 of Evans Peak section; collected by J. H. Johnson and C. D. Hier.

${ }^{54}$ Schmalhausen, J., Beiträge zur Jura-Flora Russlands : Acad. imp. sci. St.-Pétersbourg Mém., sér. 7 , tome 27 , no. 4, p. 50, 1879.

55 Saporta, Gaston de, op. cit., p. 1020.

${ }^{56}$ Grand'Eury, F. C., Flore carbonifère du département de la Loire, p. $272,1877$.

57 Seward, A. C., Fossil plants, vol. 4, p. 76, 1919.

58 Johnson, Thomas, Spermolithus devonicus, gen. et sp. nov., and other pteridosperms from the Upper Devonian beds at Kiltorkan: Roy. Dublin Soc. Sci. Proc., new ser., vol. 15, no. 23, pp. 219-220, pl. 14, fig. $3,1917$.

${ }^{59}$ Renault, B., Les plantes fossiles, p. 234, 1888.

${ }^{60}$ Fontaine, W. M., and White, I. C., The Permian or upper Carboniferous flora of West Virginia and southwestern Pennsylvania: Pennsylvania Second Geol. Survey Rept. Progress, pp. 103-104, pl. 37, figs. $11-12,1880$ 


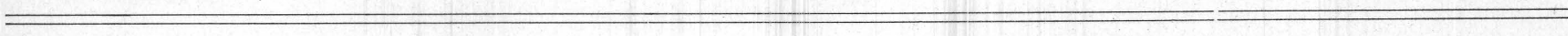

PLATES 16-18 


\section{PLATE 16}

Figures 1, 4. Lepidosirobus weberensis Read, n. sp. Fragments of strobili with the central axis exposed. Note the slenderness of the woody cylinder and the shape of the sporophyll cushions. U.S. Nat. Mus. 39155

FIGURE 2. Lepidostrobus weberensis Read, n. sp. A fragment showing the external appearance of a strobilus. U.S. Nat. Mus. 39155

Figure 3. Diplotmema patentissima (Ettingshausen) Stur. A portion of a pinna showing the extreme dissection of the lamina. The specimen is in addition somewhat macerated. U.S. Nat. Mus. 39153

Figure 5. Trichopitys whitei Read, n. sp. A slab of shale bearing two specimens. Note the repeated bifurcations of the leaves, the small size, and the thickness of the lamina. a, Trichopitys whitei; b, Cordaites sp.; c, Stigmaria verrucosa; d, Sphenopteris cheathami (Lesquereux) Read, n. comb. U.S. Nat. Mus. 39156 _ 89, 88, 82, 86

Figure 6. Cordaicarpon sp. Sketch of the seed slightly restored. U.S. Nat. Mus. 39162

Figure 7. Neuropteris heterophylla Brongniart. Fragment of the distal portion of a pinna. U.S. Nat. Mus. 39160

FIGURE 8. Asterophyllites longifolius (Sternberg) Brongniart? Fragment of a whorl of leaves showing the essential characters. U.S. Nat. Mus. 39152 


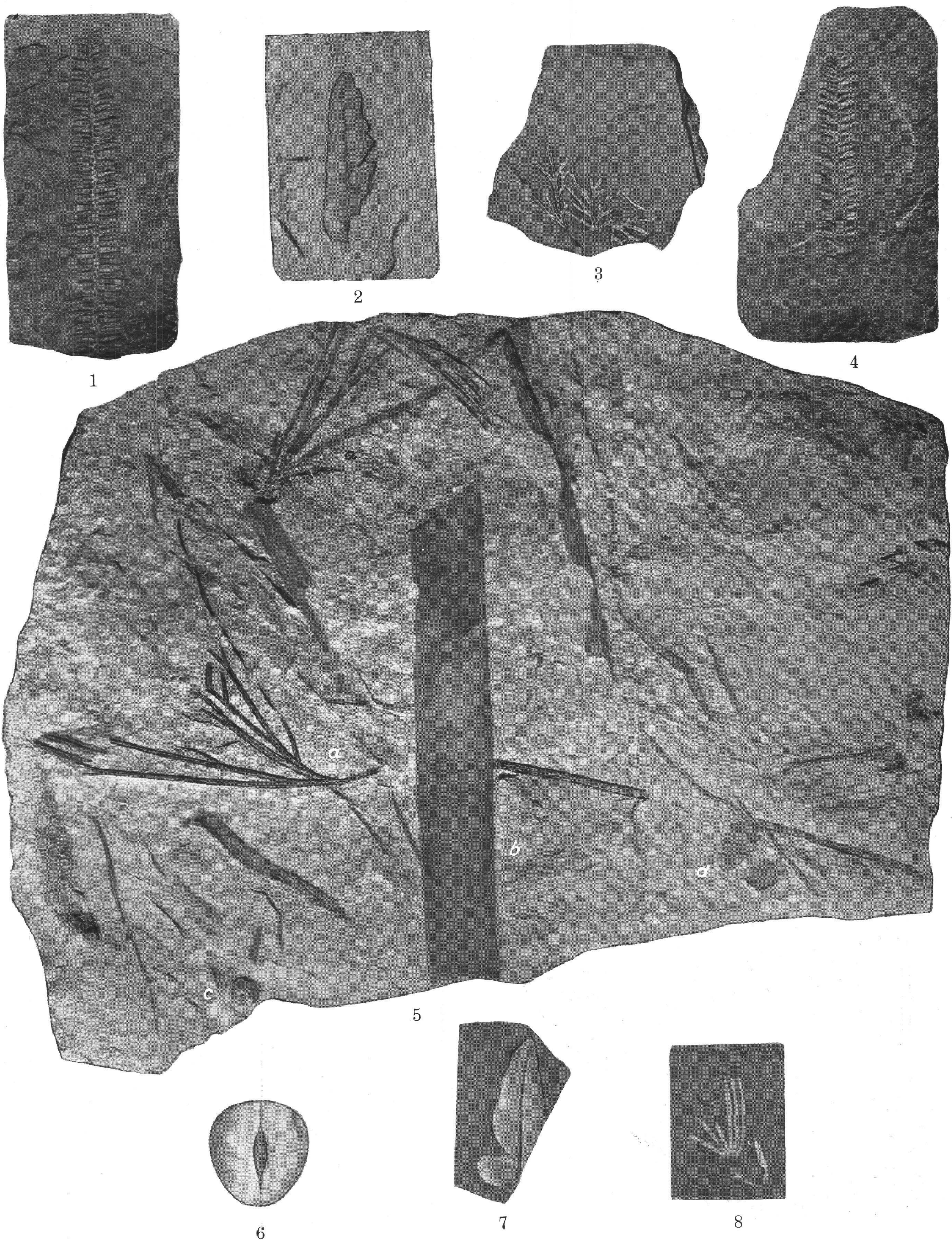

PLANTS OF POTTSVILLE AGE FROM THE MOSQUito RANGE, COLO. 

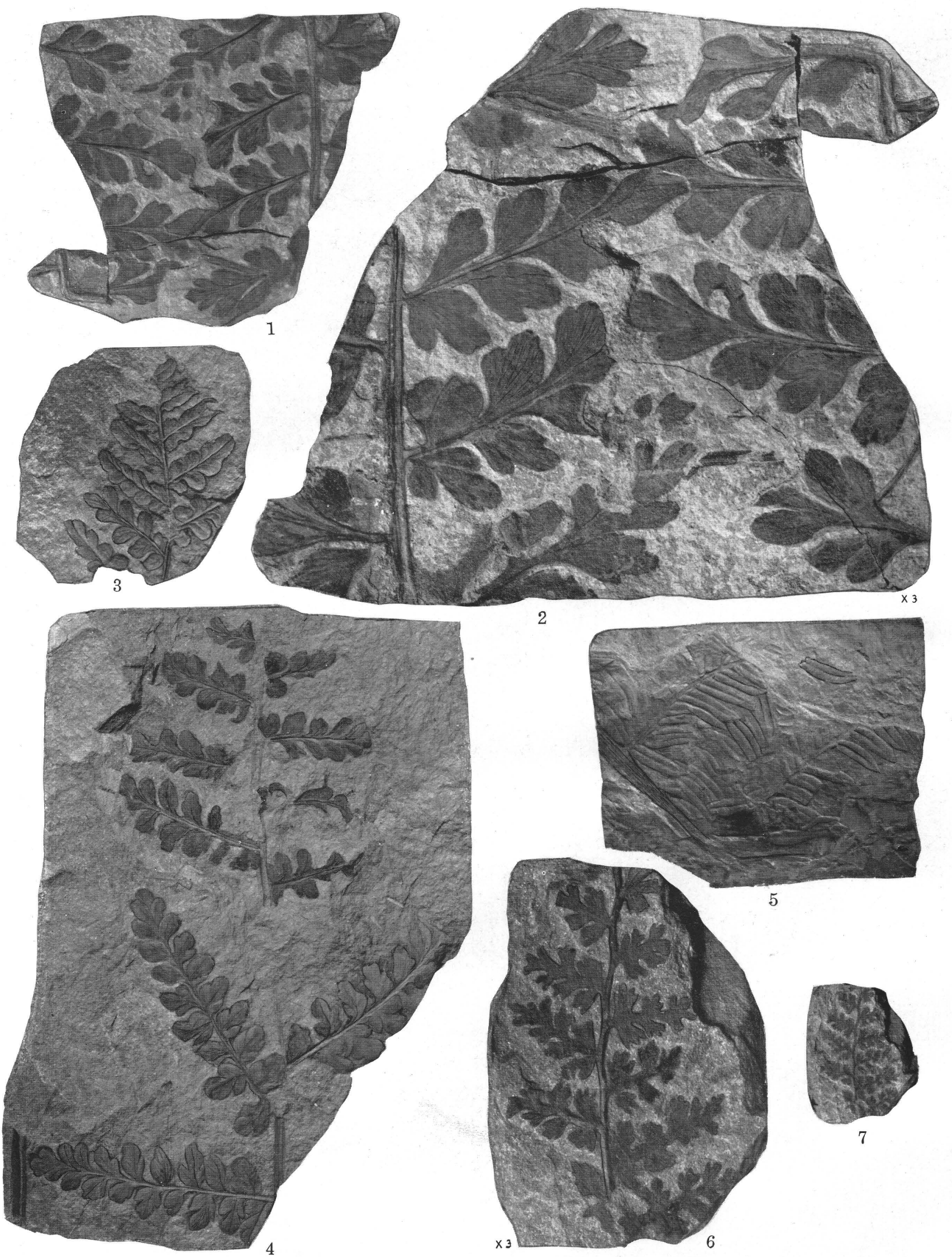

PLANTS OF POTTSVILle AGE FROM THE MOSQUiTO RANGE, COLO. 


\section{PLATE 17}

Figure 1. Sphenopteris cheathami (Lesquereux) Read, n. comb. Fragments of two pinnae showing outlines of pinnules.

U.S. Nat. Mus. 39158

Frgure 2. Sphenopteris cheathami (Lesquereux) Read, n. comb. Enlarged view of specimen in figure 1. U.S. Nat. Mus. 39158

Figure 3. Sphenopteris cheathami (Lesquereux) Read, n. comb. Fragment of distal portion of a large pinna. Compare the outline of the pinnules in this figure and figure 1. U.S. Nat. Mus. 39158

Figure 4. Sphenopteris cheathami (Lesquereux) Read, n. comb. Large fragment of a secondary rachis bearing pinnae.

Note the arrangement and spacing of the pinnae. U.S. Nat. Mus. 39158

FIGURE 5. Neuropteris aluhoschi Stur. Fragment of a penultimate pinna. U.S. Nat. Mus. 39161

Figures 6, 7. Sphenopteris cf. S. microcarpa Lesquereux. U.S. Nat. Mus. 39154 


\section{PLATE 18}

Page

FIGURE 1. Trichopitys whitei Read. Enlarged view of specimen in figure 5, plate 1, showing venation. Note the thickness of the leaf. U.S. Nat. Mus. 39156 Figures 2, 3. Dactylophyllum johnsoni Read, n. sp. Note the similarity to some of the Mesozoic Ginkgoales. U.S. Nat. Mus. 39157

FIgURe 4. Trichopitys whitei Read. Fragment of a leaf showing the apical dichotomies. U.S. Nat. Mus. 39156 ....... Figures 5, 6. Adiantites rockymontanus Read, n. sp. A pinnule. Note the corrugated surface of the lamina. U.S. Nat. Mus. 39159 


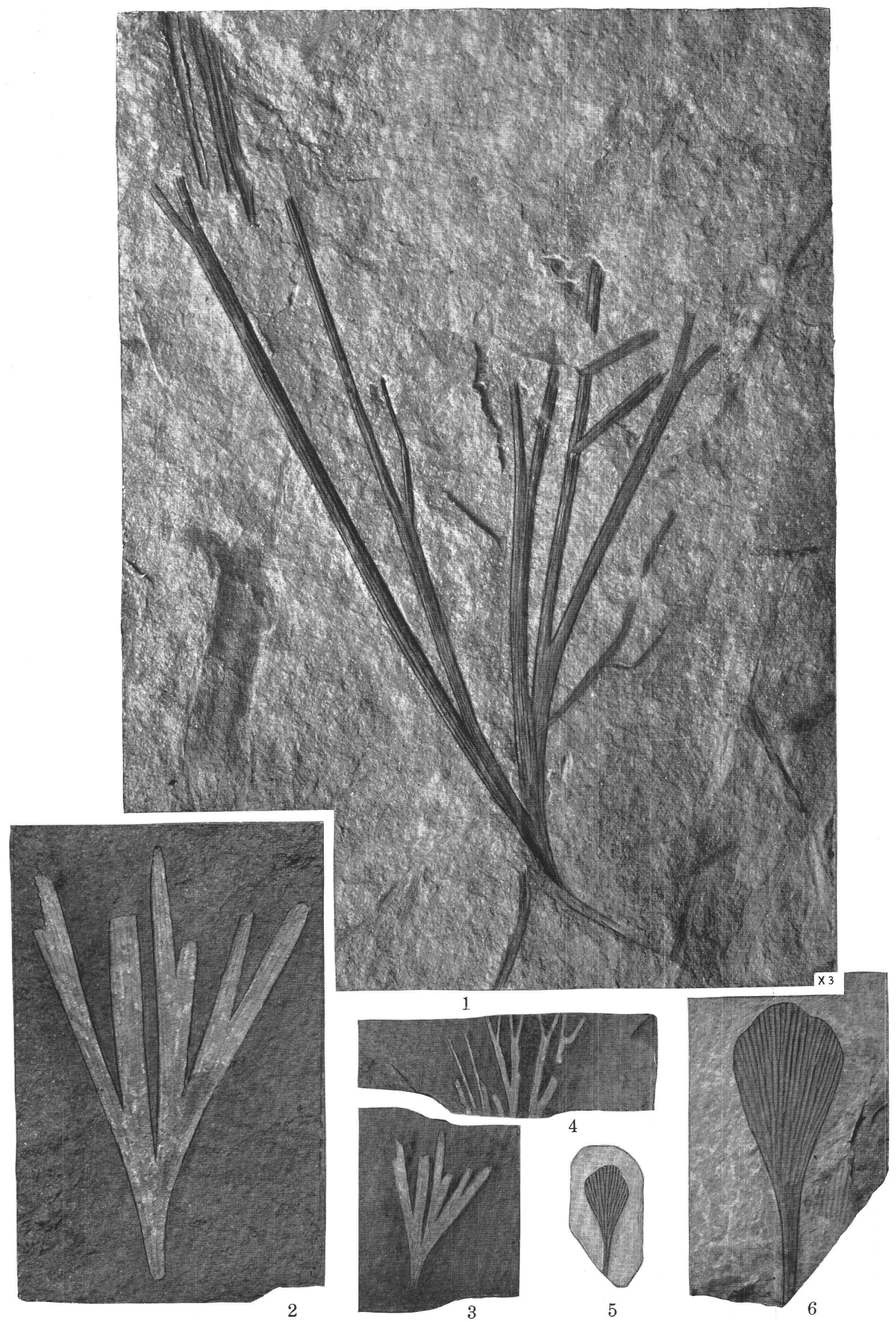

PLANTS OF POTTSVILLE AGE FROM THE MOSQUito RANGF, COLO. 